\section{Commentary: Temerity trumps dogma: The dangerous road of innovation}

\author{
Robert J. Cerfolio, MD, MBA
}

We congratulate Harrison and colleagues ${ }^{1}$ on their article concerning image-guided combined ablation and resection therapy, or "iCART," as the authors unfortunately brand it. The article shows innovation and helps blaze the trial for our inevitable future. The name may not be optimal. Marketing does matter. I fear their selected term may be confused with the much better-known form of immunotherapy, chimer antigen receptors $\mathrm{T}$ cell therapy, that has the moniker "(CAR-T)."

Irrespective of the branding, the authors' science is strong. There is little doubt that our future will have incision-less therapy for pulmonary malignancies such as selected types of ground glass opacities that harbor early adenocarcinoma as well as selected multiple metastases. There are many questions to be answered such as, Will ablative therapy only be performed in expensive hybrid operating rooms that require intraoperative cone beam computed tomography scanners, that few have access to or can afford? Will it be delivered percutaneously via the thorax or endobronchially using robotic systems? Will microwaves be the energy of choice or will it be steam or other forms of local energy? What is the true value of surgical resection of some nodules versus surgically resecting them all? Is this value proposition only based on how much pulmonary parenchyma is resected and/or preserved as well as the patient's age and the cell type? Why recommend resecting any nodules? Why not just perform a needle biopsy of 1 nodule, obtain the necessary tissue required to perform all appropriate tumor markers, and then perform

\footnotetext{
From the Department of Cardiothoracic Surgery, New York University Langone Health, New York, NY.

Disclosures: Dr Cerfolio discloses no relationships during the past 3 years, but prior relationships with Fruit Street Health, Intuitive Surgical, and Tego.

The Journal policy requires editors and reviewers to disclose conflicts of interest and to decline handling or reviewing manuscripts for which they may have a conflict of interest. The editors and reviewers of this article have no conflicts of interest.

Received for publication May 17, 2021; revisions received May 17, 2021; accepted for publication June 10, 2021; available ahead of print July 2, 2021.

Address for reprints: Robert J. Cerfolio, MD, MBA, Department of Cardiothoracic Surgery, New York University Langone Health, 530 1st Ave, Suite 9V, New York, NY 10016 (E-mail: robert.cerfolio@nyumc.org).

JTCVS Techniques 2021;9:165-6

2666-2507

Copyright (c) 2021 The Author(s). Published by Elsevier Inc. on behalf of The American Association for Thoracic Surgery. This is an open access article under the CC BY-NC-ND license (http://creativecommons.org/licenses/by-nc-nd/4.0/). https://doi.org/10.1016/j.xjtc.2021.06.040
}

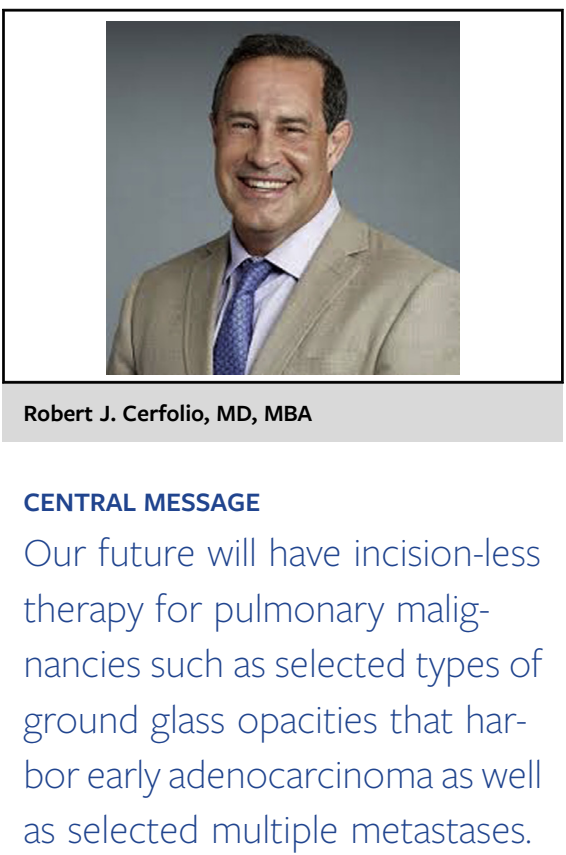

an endobronchial ultrasound to biopsy selected lymph nodes and then ablate all of the pulmonary nodules? Why resect any of them? Further, why place a wire into lesions that risk a tension pneumothorax, spreading tumor (unlikely), and more commonly dislodgment, when we can use navigational systems and tagged nodules that fluoresce? This adds complexities, especially in most places that require transport of patients from radiology with a wire in place to the operating room. Finally, what percentage of patients benefit from this type of hybrid therapy now and in the future? The authors only entered 4 patients for the study over a 17-month period.

Innovation is tough. Innovation is dangerous to patients as well as to an academic surgeon's career. Being a critic is easy as we demonstrate so aptly above. It is safe to probe, but it is hard to act and to lead. Temerity trumps dogma. The default to safety is too common, especially in medicine. The naysayers question everything and only the pioneers with vision and resiliency reach the destiny of scientific breakthrough and disruptive technology. The rest quickly follow and say how they knew all along that this way was best. More patients are helped by the vision of 1 innovator then by the eristic dogma of a thousand naysayers. The road of innovation is lined with dangerous cliffs and sharp rocks especially in the field of science. The well-traveled path is easy, safe, and smooth. Surgeons do not get to sell Dogecoins; data are needed for others to join the trial.

We congratulate the authors on their innovative sprit and the pursuit of what will unequivocally be our future: 
Ablative therapy for selected patients with selected lung lesions. Because we are scientists who care for people, each variable asked above as well as others will require careful study under the guise and rigor of the scientific method. Prospective controlled studies and may be even harder and longer to do, and prospective randomized control trials will be needed. These studies will take years, large amounts of data, and $P$ values to draw solid scientific conclusions. Do we need these? It is easy to say that more data are needed, but indeed they are.

Yet, we can be nimbler and get to the future with greater alacrity. We as both scientists and visionaries have to find an intermediate path between these diverse roads. Our patients deserve both safety and the easier and better way of innovation sooner. Leaders have vision and make it reality. We congratulate the authors on their leadership and look forward to joining them on the path they have blazed. Where we, and patients, can bask in the beautiful destination that lies at the end of the road of innovation.

\section{Reference}

1. Harrison OJ, Sarvananthan S, Tamburrini A, Peebles C, Alzetani A. Image-guided combined ablation and resection in thoracic surgery for the treatment of multiple pulmonary metastases: a preliminary case series. J Thorac Cardiovasc Surg Tech. 2021;9:156-62. 